\title{
Electro-oxidation of ethanol in acid medium using carbon- supported PtRh nanoparticles with (100) preferential orientation
}

\author{
N.G. Pereira Filho, R.F.B. Souza, A.S. Ramos, R. M. Antoniassi, A. Oliveira Neto*, \\ E. V. Spinacé* \\ Instituto de Pesquisas Energéticas e Nucleares - IPEN-CNEN/SP, Av. Prof. Lineu Prestes, 2242, \\ Cidade Universitária, 05508-900 São Paulo - SP, Brazil \\ *E-mail: espinace@yahoo.com.br; aolivei@ipen.br
}

Received: 25 October 2021 / Accepted: 6 October 2021 / Published: 10 November 2021

Carbon-supported PtRh nanoparticles with preferential (100) orientation was prepared by an alcoholreduction process using $\mathrm{KBr}$ as a shape directing agent. The electrocatalysts were characterized by EDX (energy-dispersive X-ray analysis), XRD (X-ray diffraction) and TEM (Transmission electron microscopy). The electro-oxidation of ethanol was studied by cyclic voltammetry and chronoamperometry at room temperature in acid medium. On-line differential mass spectrometry experiments were performed on a single cell of a direct ethanol fuel cell (DEFC) at $60{ }^{\circ} \mathrm{C}$ and the anodic effluents were analyzed by ATR-FTIR. PtRh/C (100) electrocatalyst showed cubic-like morphology and average nanoparticles size of $8 \mathrm{~nm}$ and provided superior DEFC performance (density power per $\mathrm{Pt}$ active area) and $\mathrm{CO}_{2}$ selectivity compared to polycrystalline $\mathrm{PtRh} / \mathrm{C}$ and commercial $\mathrm{Pt} / \mathrm{C}$ electrocatalysts.

Keywords: PtRh nanoparticles; (100) preferential orientation, electrocatalysts; ethanol; fuel cell; DEFC

\section{$\underline{\text { FULL TEXT }}$}

(C) 2021 The Authors. Published by ESG (www.electrochemsci.org). This article is an open access article distributed under the terms and conditions of the Creative Commons Attribution license (http://creativecommons.org/licenses/by/4.0/). 